Japanese and Chinese Immigrant Activists 



\section{Japanese and Chinese Immigrant Activists}

Organizing in American and International

Communist Movements, 1919-1933

JOSEPHINE FOWLER 


\section{LIBRARY OF CONGRESS CATALOGING-IN-PUBLICATION DATA}

Fowler, Josephine

Japanese and Chinese immigrant activists : organizing in American and international Communist movements, I9I9-I933 / Josephine Fowler.

p. $\mathrm{cm}$.

Includes bibliographical references and index.

ISBN-I3: 978-0-8I35-4040-5 (alk. paper)

ISBN-I3: 978-0-8I35-404I-2 (pbk. : alk. paper)

I. Communist Party of the United States of America--History. 2. Japanese Americans--Politics and government. 3. Chinese Americans--Politics and government. 4. Immigrants--United States--Political activity. I. Title.

JK239I.C5F68 2007

324.273'7508995I-dc22

2006031253

CIP

A British Cataloging-in-Publication record for this book is available from the British Library.

Copyright $\odot 2007$ by Josephine Fowler

All rights reserved

No part of this book may be reproduced or utilized in any form or by any means, electronic or mechanical, or by any information storage and retrieval system, without written permission from the publisher. Please contact Rutgers University Press, Ioo Joyce Kilmer Avenue, Piscataway, NJ 08854-8099. The only exception to this prohibition is "fair use" as defined by U.S. copyright law.

Manufactured in the United States of America 
For my mother,

Nevi Unti Fowler,

and my late father,

Joseph William Fowler 
